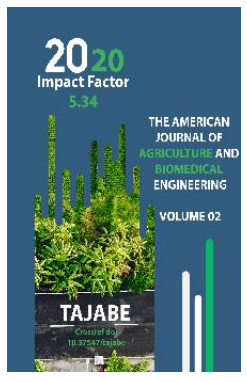

Journal Website: http://usajournalshub.c om/index,php/tajabe

Copyright: Original content from this work may be used under the terms of the creative commons attributes 4.0 licence.

\section{Harmful Intress (Planococcus Ficus) On Grapes And The Application Of The Preparation Enthomin K.E. Against Him}

\author{
S.Ubaydullaev \\ Tashkent State Agrarian University, Tashkent, Uzbekistan.
}

\section{A.Kholliev}

Tashkent State Agrarian University, Tashkent, Uzbekistan.

\title{
ABSTRACT
}

This article provides data on the harmfulness, distribution and lifestyle of the grape mealybug (Latin Planococcus ficus) in recent years in the vineyards of the republic. In order to determine the effectiveness of insecticides against mealybugs, we first carried out observations based on sex pheromones. On this basis, the preparations Entomin C.E., Nurell-D 55\% C.e. were tested in three variants. The highest efficiency was observed in the variant where Entomin C.e. was used -10,0-15,0 I / ha. In this variant, the efficiency was $87,4-88,6 \%$.

\section{KEYWORDS}

Harm, grapes, fight, mealybug, pesticide, research, results, biological effectiveness.

\section{INTRODUCTION}

Grapes are the main fruit crop in the Republic of Uzbekistan, and currently there is an acute issue of obtaining high yields of high-quality and environmentally friendly products with minimal costs. This makes it necessary to reorient horticulture from chemical protection against pests to scientifically based control of phytophages, including agrotechnical measures and the use of environmentally friendly and gentle plant protection products.
The decline in the general culture of agriculture, as well as the loss of the complexity of protective measures, their reorientation to the predominant use of the chemical method, a sharp decrease in the range and volume of use of various biological agents in gardens has sharply increased the negative consequences of large-scale uncontrolled use of highly toxic chemicals. 


\section{MATERIALS AND METHODS}

Vineyards, due to the fact that they are a perennial habitat of many pests, most require compliance with a system of protective measures throughout the season.

The most common pests in vineyards on the territory of Uzbekistan are mealybugs, aphids, and to a lesser extent, they are damaged by the colonization of leaf twists. In the absence of protective measures, the damage to the mealybug fruit can reach $80-90 \%$.

Grape mealybug (Planococcus ficus, mealybug) is a pest of grapevine. It is found mainly in southern regions with mild winters.

Females hibernate under the bark, in cracks in the bark and other protected places. In spring, at a temperature of $+6+7^{\circ} \mathrm{C}$, females wake up and feed on the bark of boles and perennial shoots for 15-20 days.

Males are rare, so reproduction is often parthenogenetic. Eggs (up to 40 eggs from one female) are laid on the bark of the shoots. From these eggs, larvae (nymphs) hatch in 1014 days, which feed on green shoots for a month. Females of the second and then third generations are more fertile, they lay 150-250 eggs on sleeves, shoots and leaves. Embryonic development lasts 8-10 days. The third generation is the most numerous and most harmful.

After hatching, the larvae form numerous colonies on clusters at the base of the peduncles and between the leaves. On damaged berries, yellow-brown spots are formed. The dead skin cracks, the berries rot. Larvae and females secrete sticky sweet juice, on which saprophytic fungi develop, polluting shoots, leaves, berries.
Optimal conditions for life are temperature $+22+25^{\circ} \mathrm{C}$ and relative air humidity $45-75 \%$. Cool rainy springs and hot summers inhibit the development of the pest.

Mass death of larvae is observed in winter at temperatures below $-15^{\circ} \mathrm{C}$. Mealybugs cause direct and indirect damage.

It is a sucking insect. Nymphs and females feed on plant sap, stunting growth and causing deformation and / or yellowing (reddening) of the leaves, sometimes accompanied by leaf fall (defoliation).

There is a decrease in photosynthesis and, consequently, the quantity and quality of the harvest decreases, the caps of the inflorescences and the affected berries of the bunches often fall off. Grape plant juice is rich in sugar but low in protein, so mealybugs must consume a lot of juice to get the protein they need for their vital activity, getting rid of excess sugars in the form of sticky honeydew that cannot be washed off from the bunch. And already on this dew, saprophytic pathogens develop, in particular, dark soot mold (Cladosporium spp). In addition to the deterioration of the presentation, this also affects the taste of the berries. Mealybug infestation of shrubs weakens the shrub and makes it susceptible to other phytopathogens (fungal diseases and other pests). The mealybug has now been proven to be a carrier of viruses, in particular the GLRaV-3 leaf roll virus (Cloning can lead to control of the leaf roll virus).

\section{PLACE AND METHOD OF RESEARCH}

Trials of the new drug Entomin k.e. (PE "Ifodaagrokimyohimoya", Uzbekistan) held in the apple orchard of the farm named after "Khusniddin yuldosh" of the Srednechirchik district of the Tashkent region. February 22, 
2019. The treatments were carried out using a hand-held sprayer at a rate of $600 \mathrm{I} / \mathrm{ha}$. The tests were carried out from 1500 hours a day, when the air temperature did not exceed +10 $12^{\circ} \mathrm{C}$, and the wind speed was within $0,5-1 \mathrm{~m} / \mathrm{s}$. The widely used preparation No. 30 oil was used as a standard. em. 9 .

\section{TEST RESULTS}

In the variant where the drug Entomin k.e was used at a rate of 10,0-15,0 I/ha. against mealybug, biological effectiveness on the day of registration was $87,4-88,6 \%$. In the reference variant, the preparation against mealy worm showed 78,0-79,9\% biological effectiveness. Experiments to test the effectiveness of the insecticide Entomin k.e. were carried out in stationary garden plots, with different density of aphid pest. The drug was tested at consumption rates: 10,0-15,0 I/ha.

Table 1.

Biological effectiveness of the drug Entomin k.e. against mealybugs in grapes. Manufacturing experience. (Tashkent region. Srednechirchik district, farm named after, "Khusniddin Yuldosh" 25.06.2019)

\begin{tabular}{|c|c|c|c|c|c|c|}
\hline \multirow{2}{*}{$№$} & Experience options & $\begin{array}{r}\text { Consumpti } \\
\text { on rate of } \\
\text { the drug, } \\
\text { l/ ha }\end{array}$ & $\begin{array}{c}\text { Harvest } \\
\text { damage, \% }\end{array}$ & $\begin{array}{c}\text { Efficiency, } \\
\text { \% }\end{array}$ & $\begin{array}{c}\text { Damage to the } \\
\text { gross crop, \% }\end{array}$ & $\begin{array}{c}\text { Efficiency, } \\
\text { \% }\end{array}$ \\
\hline 1 & Entomink.e. & 10,0 & 6,2 & $\mathbf{8 7 , 4}$ & 12,2 & 78,0 \\
\hline 2 & Entomink.e & 15,0 & 5,6 & $\mathbf{8 8 , 6}$ & 11,3 & 79,9 \\
\hline 3 & Nurell-D 55\% ae & 1,0 & 7,1 & 85,5 & 14,6 & 74,1 \\
\hline 4 & \multicolumn{2}{|c|}{$\begin{array}{c}\text { Control } \\
\text { (no processing) }\end{array}$} & 49,2 & - & 56,4 & - \\
\hline
\end{tabular}

\section{CONCLUSIONS AND RELEVANCE}

The drug Entomink.e. Showed high efficiency in the treatment against honeycorns, larvae of scale insects on an apple tree at a consumption rate of 10,0-15,0 I/ha. The preparative form, when mixed with water, quickly forms a working mixture, which makes it convenient to use. After spraying, the manifestation of phytotoxicity in the given consumption rates was not revealed.

\section{REFERENCES}

1. Bondarenko N.V., Persov M.P., Pospelov S.M. General and agricultural entomology I - M .: Kolos, 1983. - 416 p., III. (Textbooks and teaching aids for middle agricultural educational institutions).

2. Vanek G., Korchagin V.N., Ter-Simonyan N.L. Atlas of diseases and pests of fruit, berry, vegetable crops and grapes. Bratislava, Nature. M. "Agrokomizdat. 1989. - 416 p.

3. Gorbachev I.V, Gritsenko V.V, Zakhvatkin Yu.A. and other Protection of plants from 
Doi: https://doi.org/10.37547/tajabe/Volumeo2Issue08-11

pests / Ed. prof. V.V. Isaicheva. - M .: Kolos, 2002 .-- $472 \mathrm{p}$.

4. Murodov B.E, Yakhoev Zh.N. Quarantine pests of internal quarantine of the Republic of Uzbekistan // Education and science in Russia and abroad. - 2017. - No. 3 (32). -FROM. 32-36. 